\title{
Acute interstitial nephritis and DRESS syndrome without eosinophilia associated with cefepime
}

\author{
Irfan Qadri, ${ }^{1}$ Xu Zeng, ${ }^{2}$ Ruifeng Guo, ${ }^{3}$ Abhilash Koratala ${ }^{1}$
}

'Department of Nephrology, University of Florida College of Medicine, Gainesville, Florida, USA

${ }^{2}$ Department of Nephropathology, University of Florida College of Medicine, Gainesville, Florida, USA ${ }^{3}$ Department of

Dermatopathology, University of Florida College of Medicine, Gainesville, Florida, USA

\section{Correspondence to} Dr Abhilash Koratala, akoratsla@ufl.edu

Accepted 25 July 2017
To cite: Qadri I, Zeng $X$, Guo R, et al. BMJ Case Rep Published Online First: [please include Day Month Year]. doi:10.1136/bcr-2017221401

\section{DESCRIPTION}

The drug reaction with eosinophilia and systemic symptoms (DRESS syndrome) is a potentially life-threatening drug-induced reaction characterised by a severe skin eruption, fever, haematological abnormalities (eosinophilia or atypical lymphocytes) and internal organ involvement (liver is the most common). These manifestations are thought to be a type IV hypersensitivity with a delayed onset of usually 2-6 weeks after the initiation of drug therapy. ${ }^{12}$ While the pathogenesis of this condition is not well understood, mechanisms such as detoxification defects leading to reactive metabolite formation and subsequent immunological reactions, slow acetylation and reactivation of Epstein-Barr virus and human herpesvirus 6 and 7 have been proposed. ${ }^{2}$ The most common drugs associated with DRESS syndrome are the aromatic anticonvulsants (phenytoin, phenobarbital, carbamazepine) and sulfonamides. ${ }^{3}$

A 62-year-old man with poorly controlled diabetes and subacute osteomyelitis presented to the hospital with fatigue, fever and anorexia. Prior to admission, he was being treated for osteomyelitis as an outpatient for approximately 6 weeks with vancomycin $1 \mathrm{~g}$ intravenously every 12 hours and cefepime $6 \mathrm{~g}$ intravenous continuous infusion daily. Physical examination revealed tender axillary lymphadenopathy and a morbilliform, blanchable rash present on his flank and extremities (figure 1). Laboratory evaluation revealed leucocytosis, transaminitis and acute kidney injury with a serum creatinine of $3.6 \mathrm{mg} / \mathrm{dL}$ (baseline $0.8 \mathrm{mg} / \mathrm{dL}$ ). Peripheral smear demonstrated atypical lymphocytes and vacuolated neutrophils, but there was no eosinophilia. Urine microscopy revealed white blood

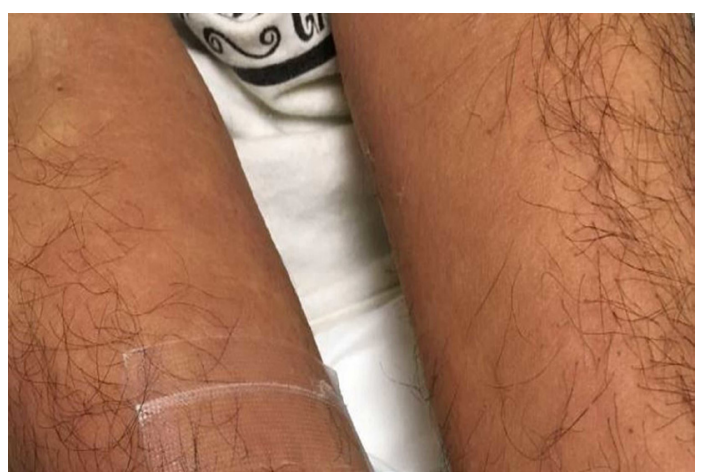

Figure 1 Erythematous rash on the upper extremities.

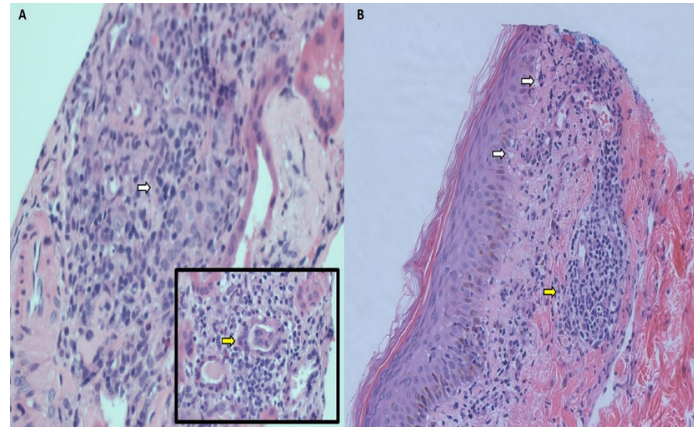

Figure 2 (A) Renal biopsy demonstrating dense interstitial infiltrate (white arrow). Tubulitis is shown in the inset (yellow arrow). (B) Skin biopsy demonstrating vacuolar interface dermatitis (white arrows) and a dense dermal lymphocytic infiltrate (yellow arrow).

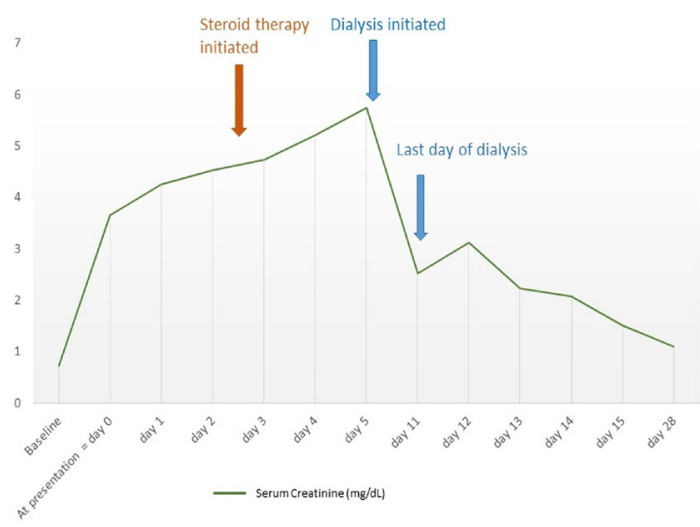

Figure 3 Graph depicting the trend of serum creatinine and response to therapy.

cell (WBC) casts without eosinophiluria. Serum complements were normal and hepatitis panel was negative. Renal biopsy demonstrated acute interstitial nephritis (AIN) and skin biopsy showed vacuolar interface dermatitis with a mixed dermal infiltrate (figure 2). He was diagnosed with DRESS syndrome based on a RegiSCAR (European Registry of Severe Cutaneous Adverse Reactions) score ${ }^{4}$ of 6 and AIN. Empiric steroid therapy was started with prednisone $1 \mathrm{mg} / \mathrm{kg} / \mathrm{day}^{5}$ Though he required renal replacement therapy for a few days, his renal function recovered subsequently (figure 3 ). His rash and transaminitis improved as well. While both vancomycin and cefepime have been implicated in the causation of DRESS syndrome, we believe cefepime is the major culprit in this case because of the high dose used. Moreover, his vancomycin trough levels were never high. 


\section{Learning points}

- Despite its name, the presence of eosinophilia is not mandatory for the diagnosis of drug reaction with eosinophilia and systemic symptoms (DRESS syndrome).

- Early diagnosis and withdrawal of the offending agent is the key to management of this condition, which otherwise is associated with high mortality rates.

- Although there are no clear guidelines regarding dose and duration of steroid therapy, early initiation of steroid therapy has shown to hasten recovery of renal function in druginduced acute interstitial nephritis, as in our case.

Contributors IQ has written the initial draft. XZ and RG have provided the pathology images and related information. AK was the attending physician on the case, revised the manuscript for critically important intellectual content and approved for final submission.
Competing interests None declared.

\section{Patient consent Obtained.}

Provenance and peer review Not commissioned; externally peer reviewed.

(c) BMJ Publishing Group Ltd (unless otherwise stated in the text of the article) 2017. All rights reserved. No commercial use is permitted unless otherwise expressly granted.

\section{REFERENCES}

1 Bocquet H, Bagot M, Roujeau JC. Drug-induced pseudolymphoma and drug hypersensitivity syndrome (drug rash with eosinophilia and systemic symptoms: DRESS) Semin Cutan Med Surg 1996;15:250-7.

2 Cacoub P, Musette P, Descamps V, et al. The DRESS syndrome: a literature review. Am J Med 2011;124:588-97.

3 Tas S, Simonart T. Management of drug rash with eosinophilia and systemic symptoms (DRESS syndrome): an update. Dermatology 2003;206:353-6.

4 Kardaun SH, Sidoroff A, Valeyrie-Allanore L, et al. Variability in the clinical pattern of cutaneous side-effects of drugs with systemic symptoms: does a DRESS syndrome really exist? Br J Dermatol 2007;156:609-11.

5 González E, Gutiérrez E, Galeano C, et al. Early steroid treatment improves the recovery of renal function in patients with drug-induced acute interstitial nephritis. Kidney Int 2008;73:940-6.

Copyright 2017 BMJ Publishing Group. All rights reserved. For permission to reuse any of this content visit http://group.bmj.com/group/rights-licensing/permissions.

BMJ Case Report Fellows may re-use this article for personal use and teaching without any further permission.

Become a Fellow of BMJ Case Reports today and you can:

- Submit as many cases as you like

- Enjoy fast sympathetic peer review and rapid publication of accepted articles

- Access all the published articles

- Re-use any of the published material for personal use and teaching without further permission

For information on Institutional Fellowships contact consortiasales@bmjgroup.com

Visit casereports.bmj.com for more articles like this and to become a Fellow 